\title{
SUSTAINABILITY OF WOOD PRODUCTIVITY OF Pinus taeda BASED ON NUTRIENT EXPORT AND STOCKS IN THE BIOMASS AND IN THE SOIL
}

\author{
Ricardo Michael de Melo Sixel ${ }^{(1) *}$, José Carlos Arthur Junior ${ }^{(2)}$, José Leonardo de Moraes \\ Gonçalves $^{(3)}$, Clayton Alcarde Alvares ${ }^{(2)}$, Gabriel Ramatis Pugliese Andrade ${ }^{(3)}$, Antonio \\ Carlos Azevedo $^{(3)}$, James Stahl ${ }^{(4)}$ and Antônio Maurício Moreira ${ }^{(5)}$
}

(1) Auditor Lead Assessor ISO 14.001 para certificação Florestal Cerflor/FSC® e certificação agrícola RAS, São Pedro, São Paulo, Brasil.
(2) Instituto de Pesquisas e Estudos Florestais, Piracicaba, São Paulo, Brasil.
${ }^{(3)}$ Universidade de São Paulo, Escola Superior de Agricultura Luiz de Queiroz, Piracicaba, São Paulo, Brasil.
${ }^{(4)}$ Klabin S/A, Fazenda Monte Alegre, Telêmaco Borba, Paraná, Brasil.
(5) Klabin S/A, Otacílio Costa, Santa Catarina, Brasil.
* Corresponding author.
E-mail: sixelr@gmail.com

\begin{abstract}
The impact of intensive management practices on the sustainability of forest production depends on maintenance of soil fertility. The contribution of forest residues and nutrient cycling in this process is critical. A 16-year-old stand of Pinus taeda in a Cambissolo Húmico Aluminico léptico (Humic Endo-lithic Dystrudept) in the south of Brazil was studied. A total of 10 trees were sampled distributed in five diameter classes according to diameter at breast height. The biomass of the needles, twigs, bark, wood, and roots was measured for each tree. In addition to plant biomass, accumulated plant litter was sampled, and soil samples were taken at three increments based on sampling depth: 0.00-0.20, 0.20-0.40, 0.40-0.60, 0.60-1.00, 1.00-1.40, 1.40-1.80, and 1.80-1.90 $\mathrm{m}$. The quantity and concentration of nutrients, as well as mineralogical characteristics, were determined for each soil sample. Three scenarios of harvesting intensities were simulated: wood removal (A), wood and bark removal (B), and wood + bark + canopy removal (C). The sum of all biomass components was $313 \mathrm{Mg} \mathrm{ha}^{-1}$. The stocks of nutrients in the trees decreased in the order $\mathrm{N}>\mathrm{Ca}>\mathrm{K}>\mathrm{S}>\mathrm{Mg}>\mathrm{P}$. The mineralogy of the Cambissolo Húmico Alumínico léptico showed the predominance of quartz sand and small traces of vermiculite in the silt fraction. Clay is the main fraction that contributes to soil weathering, due to the transformation of illite-vermiculite, releasing $K$. The depletion of
\end{abstract}




\begin{abstract}
nutrients from the soil biomass was in the order: $\mathrm{P}>\mathrm{S}>\mathrm{N}>\mathrm{K}>\mathrm{Mg}>\mathrm{Ca}$. Phosphorus and $\mathrm{S}$ were the most limiting in scenario A due to their low stock in the soil. In scenario $B$, the number of forest rotations was limited by N, K, and S. Scenario C showed the greatest reduction in productivity, allowing only two rotations before $\mathrm{P}$ limitation. It is therefore apparent that there may be a difference of up to 30 years in the capacity of the soil to support a scenario such as $\mathrm{A}$, with a low nutrient removal, compared to scenario $\mathrm{C}$, with a high nutrient removal. Hence, the effect of different harvesting intensities on nutrient availability may jeopardize the sustainability of $P$. taeda in the short-term.
\end{abstract}

Keywords: soil fertility, nutrient cycling, forest management.

\title{
RESUMO: SUSTENTABILIDADE DA PRODUTIVIDADE DE MADEIRA DE Pinus taeda COM BASE NA EXPORTAÇÃO E NO ESTOQUE DE NUTRIENTES NA BIOMASSA E NO SOLO
}

\begin{abstract}
Os impactos das práticas de manejo intensivo sobre a sustentabilidade da produção florestal dependem da manutenção da fertilidade do solo. A contribuição dos resíduos florestais e da ciclagem de nutrientes nesse processo é crucial. Avaliou-se uma plantação de 16 anos de idade de Pinus taeda em um Cambissolo Húmico Alumínico léptico de textura argilosa, relevo ondulado, no meio-sul catarinense. Dez árvores foram amostradas em cinco classes de diâmetro, de acordo com a distribuição de diâmetro à altura do peito. A biomassa de acículas, galhos, casca, madeira e raizes foi medida para cada árvore. Além da biomassa vegetal, amostraram-se serapilheira acumulada e solo nas camadas de 0,00-0,20; 0,20-0,40; 0,40-0,60; 0,60-1,00; 1,00-1,40; 1,40-1,80, e 1,80-1,90 m. A concentração de nutrientes, o balanço de nutrientes e a caracterização mineralógica foram determinados a partir das amostras de solo coletadas. Três cenários de intensidade de colheita foram simulados, considerando a remoção de madeira (A), madeira e casca (B) e madeira, casca e copa (C). A soma de todos os componentes da biomassa foi de $313 \mathrm{Mg} \mathrm{ha} \mathrm{H}^{-1}$. O estoque de nutrientes na árvore foi $N>C a>K>S>M g>P$. A mineralogia do Cambissolo Húmico Alumínico léptico evidenciou a predominância de areia de quartzo e pequenos traços de vermiculita na fração silte. A argila éa principal fração que contribui para o intemperismo do solo em razão da transformação de ilita-vermiculita liberando K. O esgotamento dos nutrientes do solo a partir da biomassa foi: $P>S>N>K>M g>C a$. Fósforo e $S$ permaneceram como os nutrientes mais limitantes no cenário A, por causa dos seus baixos estoques disponíveis no solo. No cenário $B$, o número de rotações florestais foi limitado para $N, K$ e $S$. O cenário $C$ resultou na maior diminuição de produtividade, e limitado pelo $P$, apresentando apenas duas potenciais rotações de cultivo para esse nutriente. Dessa forma, evidenciou-se, pelo número potencial de rotações de cultivo, que entre o cenário $A$, menos exaustivo, e cenário $C$, mais exaustivo, uma diferença de até 30 anos na capacidade de suporte do solo. Assim, o efeito de diferentes intensidades de colheita sobre a disponibilidade de nutrientes pode comprometer a sustentabilidade do P. taeda em longo prazo.
\end{abstract}

Palavras-chave: fertilidade do solo, ciclagem de nutrientes, manejo florestal.

\section{INTRODUCTION}

The ability to predict long-term forest productivity is a challenge in forest management (Adams et al., 2000; Gonçalves et al., 2014). Understanding the processes involved in the production of forest resources allows the establishment of management criteria best suited for specific sites and allows the determination of the upper and lower limits of a secure management system. Forest management practices should be based on knowledge of the characteristics and conditions of the "forest system" established at a given site.

Although Pinus taeda is considered a species of low-nutrient demand, its productivity depends primarily on the content and cycling of nutrients stored on the forest floor, provided mainly by forest residues (Schumacher and Poggiani, 1993). Although the use of forest residues to produce energy is important in industrial economic/energetic aspects, this use can have a significant impact on the productive capacity of soils, requiring a higher frequency of nutritional supplementation.

Knowledge of nutrient cycling in forest ecosystems is a key prerequisite to understanding and predicting nutritional effects on forest growth. Similarly, knowledge of the biomass and nutrient content distributions in different compartments and developmental stages of forest stands is essential for defining the most appropriate management practices. 
The objectives of this study were to quantify the dry matter content and nutrient stocks in the above- and belowground biomass of a 16-year-old stand of Pinus taeda; to characterize the potential for release of nutrients from primary and secondary minerals and the nutrient stocks in a Cambissolo Húmico Alumínico léptico; to quantify the removal of nutrients through harvesting of wood and forest components; and to estimate forest sustainability based on the nutrient stocks in the plant/soil system.

\section{MATERIAL AND METHODS}

\section{Study area}

A 16-year-old commercial stand of Pinus taeda was studied in the municipality of Otacílio Costa, State of Santa Catarina, southern Brazil, approximately at geographic coordinates $27^{\circ} 21^{\prime} \mathrm{S}$ and $50^{\circ} 05^{\prime} \mathrm{W}$ and $856 \mathrm{~m}$ altitude. Climate at the site is classified as Cfb (Köppen climate system), i.e., humid subtropical climate, with a temperate summer, no dry season, average annual temperature of $16.1^{\circ} \mathrm{C}$, annual rainfall of $1,750 \mathrm{~mm}$, and annual relative humidity of $80 \%$ (Alvares et al., 2013a,b; 2015 ). The annual potential evapotranspiration is approximately $670 \mathrm{~mm}$, with no significant drought stress (water surplus of $1,000 \mathrm{~mm}$ ).

The study area is in the Paraná River Basin, in the Rastro River geological formation, Passa Dois Group, Permian (Santa Catarina, 1986). The predominant lithology is sedimentary rocks, composed of reddish sandstones, purplish or whitish, with fine to medium granulation, intercalated with argillites and siltstones of the same color (Betiollo, 2006), and composed mainly of mineral quartz, feldspar, and mica (Machado et al., 2001). The soil in the study area is a clayey, mixed, active, acid, mesic Cambissolo Húmico Alumínico léptico (Humic Endo-lithic Dystrudept), with base saturation of $2 \%$ and $\mathrm{Al}$ saturation above $97 \%$. The soil profile has a typical sequence of horizons, such as A1-AB-BA-Bi-BC-C, moderate drainage, smooth wavy relief, soil colors ranging from dark yellowish brown to grayish brown, and an average depth of $1.50 \mathrm{~m}$.

The forest stands were managed with no thinning and planted by seminal propagation. Trees were spaced at $2.5 \times 2.5 \mathrm{~m}\left(1,600\right.$ trees ha $\left.{ }^{-1}\right)$. Soil preparation was carried out with a bulldozer pulling a ripper to a depth of $0.40 \mathrm{~m}$. Seedlings were planted manually, and silvicultural maintenance, such as control of weeds and leaf cutting ants, was conducted until these interferences were no longer significant to tree growth (about three years). Fertilization (planting and maintenance) was not carried out because this practice is not generally adopted in Pinus taeda plantations.

\section{Biomass sampling}

A forest inventory was conducted for dendrometric characterization of the stands studied. In 230 ha of forest stands, 23 plots of $20 \times 30 \mathrm{~m}$ were set up. Diameter at breast height (DBH) of all the trees was measured, and the total height of only the first row of each plot. Trees were selected based on diameter distribution for biomass sampling. In a representative stand of the forest site, 10 trees were selected and divided into five diameter classes, as follows: four trees with average $\mathrm{DBH}$, two trees with average $\mathrm{DBH}-1$ standard deviation (sd), two trees with average $\mathrm{DBH}+1 \mathrm{sd}$, one tree with average $\mathrm{DBH}-2 \mathrm{sd}$, and one tree with average $\mathrm{DBH}+2$ sd (Table 1 ).

The trees selected for biomass evaluation were felled. Tree needles and live and dead branches were manually separated and weighed. The total height, $\mathrm{DBH}$, and stem diameter every $2 \mathrm{~m}$ were measured to calculate the stem volume with bark. At every $2 \mathrm{~m}$, stem sectional cuts were performed to remove wood discs of $0.03 \mathrm{~m}$ thickness. In the laboratory, the bark and wood were separated and the fresh weight was measured, and then the mass of each individual tree was calculated. The wood discs were measured to calculate the stem volume without bark. After weighing each component, samples of needles and live and dead branches were removed for further processing in the laboratory.

Table 1. Height, diameter at breast height (DBH), and volume (wood and bark) from sampled trees collected in Otacílio Costa, SC, Brazil

\begin{tabular}{lrrrr}
\hline \multirow{2}{*}{ Tree size $^{(1)}$} & \multirow{2}{*}{ Height } & \multirow{2}{*}{ DBH $^{(2)}$} & \multicolumn{2}{c}{ Volume } \\
\cline { 4 - 5 } & $\mathrm{m}$ & $\mathrm{cm}$ & \multicolumn{2}{c}{$\mathrm{m}^{3} /$ tree } \\
\cline { 4 - 5 } & & & 0.080 & 0.020 \\
$\bar{x}-2 s$ & 16.3 & 13.1 & 0.109 & 0.026 \\
$\bar{x}-1 s$ & 16.5 & 15.8 & 0.129 & 0.026 \\
$\bar{x}-1 s$ & 18.1 & 17.1 & 0.248 & 0.072 \\
$\bar{x}$ & 18.1 & 21.9 & 0.326 & 0.073 \\
$\bar{x}$ & 20.4 & 22.6 & 0.378 & 0.078 \\
$\bar{x}$ & 23.0 & 23.1 & 0.291 & 0.072 \\
$\bar{x}$ & 20.2 & 23.2 & 0.589 & 0.100 \\
$\bar{x}+1 s$ & 22.9 & 28.6 & 0.502 & 0.120 \\
$\bar{x}+1 s$ & 21.8 & 29.4 & 0.827 & 0.175 \\
$\bar{x}+2 s$ & 23.5 & 33.7 & 0.348 & 0.076 \\
$\bar{x}$ & 20.1 & 22.9 & 0.202 & 0.012 \\
$s$ & 2.7 & 6.5 & 67.902 & 62.810 \\
CV (\%) & $13)$ & 28.3 &
\end{tabular}

(1) Four trees were selected with DBH, two trees with DBH equal to the average DBH - 1 standard deviation (s), two trees with $\mathrm{DBH}$ equal to the average $\mathrm{DBH}+1 \mathrm{~s}$, one tree with DBH equal to the average $\mathrm{DBH}-2 \mathrm{~s}$, and one tree with $\mathrm{DBH}$ equal to the average $\mathrm{DBH}+2 \mathrm{~s} ;{ }^{\left({ }^{2}\right)}$ Diameter at breast height; ${ }^{\left({ }^{3}\right)} \mathrm{CV}$ : coefficient of variation. 
Roots were sampled around each tree selected by means of trenches opened with dimensions equivalent to the planting space $\left(6.25 \mathrm{~m}^{2}\right)$. In the area of the trench, litterfall was removed and the trench was excavated to a depth of $0.20 \mathrm{~m}$, using hoes and shovels. The tree stumps were then hoisted with a backhoe. Below $0.20 \mathrm{~m}$, the remaining roots were removed using the backhoe, hoes, and shovels up to a depth of $1.90 \mathrm{~m}$. The excavated soil was carefully checked in a manual way for root collection. All collected roots were weighed. The total green weight of roots was determined on a precision scale with 100 -g increments. Root samples were taken for determination of moisture and nutrient content. The total length of coarse primary roots was also measured.

Samples of needles and branches (live and dead) were weighed in the laboratory using analytical scales to determine fresh weight. The same procedure was carried out for the wood discs after manual separation of the bark and stem. These samples were dried in an oven for $72 \mathrm{~h}$ at $65^{\circ} \mathrm{C}$, weighed (dry mass determination), and processed in a grinder - nutrient contents were determined according to the methods proposed by Malavolta et al. (1989).

Wood volume with and without bark was calculated according to the Smalian method (Smalian, 1837). Equations to estimate wood and bark volume were fitted by relating the sectional area at $1.30 \mathrm{~m}$ above ground level (DBH, diameter at breast height) with the individual volume (with and without bark) of the sampled trees. These equations allowed estimation of the volumes of the trees within the inventory plots. Similarly, equations were applied to correlate the sectional area of $1.30 \mathrm{~m}$ with the dry biomass of each tree component, estimating the dry weight of each component for the trees in the inventory plots. The biomass per tree and nutrient per compartment estimates were used in conjunction with the dendrometric data from the inventory sampling to determine forest nutrient content per hectare. The most appropriate equation was selected based on the coefficient of determination $\left(R^{2}\right)$ and the standard error of estimate (Syx).

\section{Soil sampling}

In the same litterfall sampling sites, soil samples were collected at the depths of 0.00-0.20, 0.20-0.40, 0.40-0.60, 0.60-1.00, 1.00-1.40, 1.40-1.80, and $1.80-1.90 \mathrm{~m}$. To evaluate mineralogical attributes, a trench was opened and a soil sample was collected from the same layers mentioned above. Undisturbed soil samples were also collected in the same layers to determine bulk density, calculated by the ratio between soil dry mass and the Kopeck ring volume (Embrapa, 1997). The soil samples were oven dried for $72 \mathrm{~h}$ at $40-45^{\circ} \mathrm{C}$ and sieved $(2 \mathrm{~mm})$, and nutrient contents were determined according to the methods proposed by Raij et al. (2001).
The samples for mineralogical analyses were prepared according to procedures described by Jackson (1973). Dry soil samples were treated with $\mathrm{H}_{2} \mathrm{O}_{2}(30 \%$, v/v) for elimination of organic matter. A dithionite-citrate-bicarbonate treatment was applied for removal of $\mathrm{Fe}$ oxides. The sand fraction (2,000-63 $\mathrm{mm})$ was retained by sieving, and the supernatant containing silt plus clay fractions was dispersed in distilled water. The clay fraction was obtained from the supernatant after several cycles in a centrifuge at $700 \mathrm{rpm}$. Clay fraction samples were saturated with $\mathrm{K}$ and $\mathrm{Mg}$ using $1 \mathrm{~mol} \mathrm{~L}^{-1}$ solutions of $\mathrm{KCl}$ and $\mathrm{MgCl}$. The excess of $\mathrm{Cl}^{-}$was removed after several washings using ethanol and distilled water, until testing negative with $\mathrm{AgNO}_{3}$.

For the clay fraction, one sample containing $\mathrm{Fe}$ oxides and five free of $\mathrm{Fe}$ oxides were analyzed by $\mathrm{X}$ ray diffraction (XRD). The samples free of Fe oxides were examined as follows: three for $\mathrm{K}$-saturated samples (room temperature, $30^{\circ} \mathrm{C}$, and $500{ }^{\circ} \mathrm{C}$ ), one $\mathrm{Mg}$-saturated at room temperature, and the last dissolved with ethylene glycol (in $\mathrm{Mg}$ saturated). The sand and silt fractions were analyzed as powder mountings (randomly oriented), and the clay fraction as oriented slides. The diffractometer used was a Rigaku Miniflex II system equipped with a graphite monochromator and $\mathrm{CuKa}$ radiation, operating at $15 \mathrm{~mA}$ and $30 \mathrm{kV}$. The samples were run from 2 to $30^{\circ}$ $2 \theta, 0.02^{\circ} 2 \theta$ of step size and scan speed of $1^{\circ} 2 \mathrm{q} \mathrm{min}^{-1}$.

\section{Litter sampling}

An area of $2.5 \times 2.5 \mathrm{~m}$ was demarcated around each of the 10 selected trees (Table 1) to ensure that the tree remained in the center of the plot. Accumulated litter, i.e., the litter accumulated over 16 years of forest growth, on this plot was sampled at four points using a $0.05 \mathrm{~m}$ height $\times 0.30 \mathrm{~m}$ depth metal ring. Two samples were collected from the rows and two from between the rows. The plant material deposited was sampled in three distinct decomposition strata: 1) non-decomposed, 2) slightly decomposed, and 3) highly decomposed litter. Separation of the litter was based on color and physical characteristics. Needles were the main component of the sampled litter. The samples were homogenized per strata and per tree only when they were sent for chemical analysis.

Litter production (deposition) was sampled in three $20 \times 30 \mathrm{~m}$ plots, with six collectors per plot distributed diagonally. Three collectors were set up in the row, and three collectors between the rows. The collectors were made of shading screen $(50 \%)$ with a surface area of $0.25 \mathrm{~m}^{2}(0.5 \times 0.5 \mathrm{~m})$ suspended at $0.5 \mathrm{~m}$ above the ground. Sampling was conducted over a 12-month period in the last week of each month. The samples from each collector were weighed individually. Every month, a homogenized sample was collected from plots to conduct chemical analyses. Litter samples were oven dried for 
$72 \mathrm{~h}$ at $65^{\circ} \mathrm{C}$, weighed (dry mass determination), processed in a grinder, and analyzed according to Malavolta et al. (1989).

The litter decomposition rate was estimated according to the Olson method (Olson, 1963), where the litter mass accumulated on the ground in dynamic equilibrium and the litter mass produced annually allow calculation of the constant for litter decomposition (' $k$ '). Based on the $\mathrm{k}$ value, the average time required for the renewal of the litter layer on the soil and the time period required for decomposition of $50 \%(0.693 / \mathrm{k})$ and $95 \%(3 / \mathrm{k})$ of the litter were estimated according to Shanks and Olson (1961).

\section{Sustainability scenarios}

The following three harvesting intensities were used to assess the long-term sustainability of production and the related potential rotations: Scenario A - characterized by less removal of nutrients in which only the wood is removed from the system; Scenario B - the wood and the bark are removed; Scenario C - wood, bark, needles and branches (dead and live) are removed. In all these scenarios, no fertilization for nutrient replacement was carried out. In this region, fertilization for nutrient replacement is not a common practice. To calculate the potential number of rotations, the nutrients in the tree biomass (needles, live and dead branches, bark, wood, and roots) and litter were added to the stocks of soil nutrients (up to $1.00 \mathrm{~m}$ deep). From this sum, the nutrients withdrawn from the components in the different scenarios were successively subtracted for each rotation until nutrient exhaustion. Using a weather station located $2 \mathrm{~km}$ from the study site (Promab, 2011), nutrient inputs based on rainfall were estimated as $3.0 \mathrm{~kg} \mathrm{ha}^{-1} \mathrm{yr}^{-1}$ of $\mathrm{NO}_{3}^{-}$, $0.19 \mathrm{~kg} \mathrm{ha}^{-1} \mathrm{yr}^{-1}$ of $\mathrm{P}, 3.46 \mathrm{~kg} \mathrm{ha}^{-1} \mathrm{yr}^{-1}$ of $\mathrm{K}$, $7.21 \mathrm{~kg} \mathrm{ha}^{-1} \mathrm{yr}^{-1}$ of $\mathrm{Ca}$, and $1.61 \mathrm{~kg} \mathrm{ha}^{-1} \mathrm{yr}^{-1}$ of $\mathrm{Mg}$. Other pathways of outputs (erosion, leaching, and volatilization) and inputs (aerosols, fertilization, weathering of primary minerals, and biological fixation) were not considered.

\section{RESULTS AND DISCUSSION}

\section{Pinus taeda stand}

The $P$. taeda stand had an average height of $20 \mathrm{~m}, 0.227 \mathrm{~m} \mathrm{DBH}, 94.7 \%$ survival rate, a high volume of wood production $\left(610 \mathrm{~m}^{3} \mathrm{ha}^{-1}\right)$, and a mean annual increment (MAI) of $38 \mathrm{~m}^{3} \mathrm{ha}^{-1} \mathrm{yr}^{-1}$ (without bark). The results are consistent with the average productivity of major forest companies in Brazil (Munhoz, 2011; Gonçalves et al., 2013).

The equations to estimate biomass of tree components and the volume of wood with and without bark, with a sectional area of $1.30 \mathrm{~m}$ as the independent variable, were highly significant (Table 2). These results show the consistency of this variable in dendrometric models to estimate volume and the biomass components of trees, corroborating other authors (Soares and Hosokawa, 1984; Brito et al., 1984; Mello and Gonçalves, 2008).

The high productivity of the P. taeda stand indicates that local conditions were adequate for tree growth. No drought was observed in the water balance in the region, and the seasonal temperature was considered to be the main limiting factor. Physical and chemical properties of the soil and their relationship with the productivity of $P$. taeda were studied by Bellote and Dedecek (2006) and they found that the productivity of this species was mainly affected by water availability in the soil and resistance to root penetration.

The stocks of soil nutrients are characterized by large differences in $\mathrm{N}$ concentrations in the soil surface and subsurface layers, and decreasing concentrations with depth (Table 3). The $\mathrm{K}$ and $\mathrm{Ca}$ stocks tended to be greater in deeper soil layers, and

Table 2. Equations for estimating wood volume (with and without bark) and for biomass of tree components in 16-year-old Pinus taeda collected in Otacílio Costa, SC, Brazil

\begin{tabular}{llcccc}
\hline Component & \multicolumn{1}{c}{ Equation } & $\mathbf{R}^{2}$ & Sxy & $\mathbf{p}$ & $\mathbf{n}$ \\
\hline Needle & $\hat{\mathrm{y}}=-4.08^{*}+203.80^{*} \mathrm{x}$ & 0.87 & 1.97 & $<0.0001$ & 10 \\
Live branche & $\hat{\mathrm{y}}=-4.56^{*}+266.29^{*} \mathrm{x}$ & 0.91 & 2.10 & $<0.0001$ & 10 \\
Dead branche & $\hat{\mathrm{y}}=-10.4^{\mathrm{ns}}+576.12^{*} \mathrm{x}$ & 0.90 & 7.57 & $<0.0873$ & 9 \\
Bark & $\hat{\mathrm{y}}=-1.23^{*}+398.59^{\mathrm{ns}} \mathrm{x}$ & 0.98 & 2.30 & $<0.0001$ & 10 \\
Wood & $\hat{\mathrm{y}}=-17.48^{\mathrm{ns}}+3699.11^{*} \mathrm{x}$ & 0.97 & 1.97 & $<0.0001$ \\
Root & $\hat{\mathrm{y}}=-0.22^{\mathrm{ns}}+811.34^{*} \mathrm{x}$ & 0.93 & 5.59 & $<0.0001$ & 10 \\
Volume with bark & $\hat{\mathrm{y}}=-0.02^{*}+11.75^{*} \mathrm{x}$ & 0.98 & 0.05 & $<0.0001$ & 10 \\
Volume without bark & $\hat{\mathrm{y}}=-0.08^{*}+9.77^{*} \mathrm{x}$ & 0.97 & 0.05 & $<0.0001$ & 10 \\
\hline
\end{tabular}

$\mathrm{x}=$ sectional area of DBH $\left(\mathrm{m}^{2}\right)$; n: amount of sample trees; ${ }^{*}$ and ${ }^{\mathrm{ns}}$ : values of the coefficients significant at $5 \%$ and not significant by $t$ test (Student), respectively. 
this is directly associated with soil mineralogy and nutrient release mechanisms.

\section{Soil mineralogy and nutrient availability}

The XRD spectra for the clay samples saturated with $\mathrm{Mg}$ and indicate the presence of the following minerals: kaolinite, identified by the disappearance of 0.7 and $0.36 \mathrm{~nm}$ peaks after heating at $500{ }^{\circ} \mathrm{C}$; illite, identified by the persistence of peaks at $1.0,0.5$, and $0.33 \mathrm{~nm}$ after all treatments, found at all depths, but especially at a depth greater than $1.40 \mathrm{~m}$; and vermiculite, identified after the basal spacing expanded to $1.34 \mathrm{~nm}$ after $\mathrm{Mg}$ plus ethylene glycol, and contraction to $1.0 \mathrm{~nm}$ after $\mathrm{K}$ saturation and heating $\left(300\right.$ and $\left.500^{\circ} \mathrm{C}\right)$ (Figure 1$)$. The intensity of vermiculite peaks increased from $1.40 \mathrm{~m}$ deep on up to the 0.00-0.20 m layer. In addition, small amounts of quartz and smectite (expanding to $1.8 \mathrm{~nm}$ after glycolation) increased towards the surface of the soil.

The mineralogical composition of the soil may be a source of Kions since the transformation sequence implies a decrease in the layer charge and $\mathrm{K}$ release. The irrationality of peaks 001 and 002 in the spectra of $\mathrm{Mg}$ saturated clays (Figure 1) is strong support for such reasoning (Moore and Reynolds, 1997).

The desilication process is related to the weathering of primary silicates and the neosynthesis of secondary silicated clay minerals. The rate of base and silicon loss by the profile determined the Si:Al ratio in the secondary minerals formed. The existence of kaolinite (1:1 mineral) in this soil suggests that the degree of desilication is medium to strong (monosialitization to alitization) (Antonello et al., 2002). Kaolinite is the most common clay mineral in Brazilian soils due to the moist and warm climate that predominates in tropical regions (Kämpf et al., 2009).

Table 3. Stock of nutrients available in different soil layers, in 16-year-old Pinus taeda stands collected in Otacílio Costa, SC, Brazil

\begin{tabular}{lcrrrrr}
\hline Depth & \multicolumn{1}{c}{$\mathbf{N}$} & \multicolumn{1}{c}{ P } & \multicolumn{1}{c}{ K } & Ca & Mg & \multicolumn{1}{c}{ S } \\
\hline \multicolumn{1}{c}{$\mathrm{m}$} & \multicolumn{7}{c}{$\mathrm{kg} \mathrm{h}^{-1}$} \\
$0.00-0.20^{(1)}$ & $351.0^{(2)}$ & 7.3 & 61.8 & 89.6 & 43.4 & 36.3 \\
$0.20-0.40$ & 315.0 & 5.6 & 41.2 & 96.4 & 40.8 & 29.7 \\
$0.40-0.60$ & 173.0 & 4.9 & 36.0 & 93.6 & 38.9 & 38.1 \\
$0.60-1.00$ & 134.8 & 8.0 & 82.4 & 182.4 & 78.7 & 56.7 \\
$1.00-1.40$ & 90.6 & 4.9 & 195.6 & 190.4 & 75.4 & 17.6 \\
$1.40-1.80$ & 54.8 & 7.2 & 308.9 & 181.6 & 81.6 & 14.0 \\
$1.80-1.90$ & 18.7 & 1.1 & 66.9 & 45.2 & 19.1 & 3.6 \\
Sum & $1,138.0$ & 39.1 & 792.8 & 879.2 & 377.9 & 196.1 \\
\hline
\end{tabular}

(1) Concentration of nutrients and density of the soil layer obtained at the midpoint of each layer. ${ }^{(2)}$ Only N mineralization potential (Gonçalves et al., 2001).
The pedogenetic evolution of the soil profile and its minerals are important for nutrient availability (Norrish, 1973). The sequence of transformations from illite to vermiculite releases $\mathrm{K}$ to the soil solution as the interlayer is gradually opened and the layer charge decreases (Fanning et al., 1989). Concurrently, large cations such as $\mathrm{Ca}$ and $\mathrm{Mg}$ can occupy the interlayer. In a further stage, the vermiculite (2:1 mineral) becomes unstable due to the loss of $\mathrm{Si}$ from the solution (leaching), and 1:1 phases become more stable, kaolinite being the most common.

The release of $\mathrm{K}$ by minerals to the soil solution is likely triggered by the weathering of illite or primary mica minerals, transformed into other clay minerals such as vermiculite. This process is widely reported in the soil environment (Banfield and Eggleton, 1990) and takes place through the gradual loss of layer charge in a mica/illite structure and the gradual formation of vermiculite layers (with lower layer charge and less potassium within the interlayer). We did not perform a thorough analysis of this process in this study. However, we observed a decrease in the intensity of illite basal peaks in the XRD patterns, while the basal peaks assigned to expandable clays increase from the saprolite to surface horizons. This showed that the transformation is probably occurring in the Cambissolo Húmico Alumínico léptico (Humic Endo-lithic Dystrudept), although a more detailed study is necessary to prove the transformation under our conditions. Thus, this issue remains open for further detailed studies.

The high humidity and low temperature conditions of the study site allow high amounts of organic matter to remain in the soil. These compounds are very effective for complexing $\mathrm{Al}$ and $\mathrm{Fe}$ and halting the formation of metal oxides such as

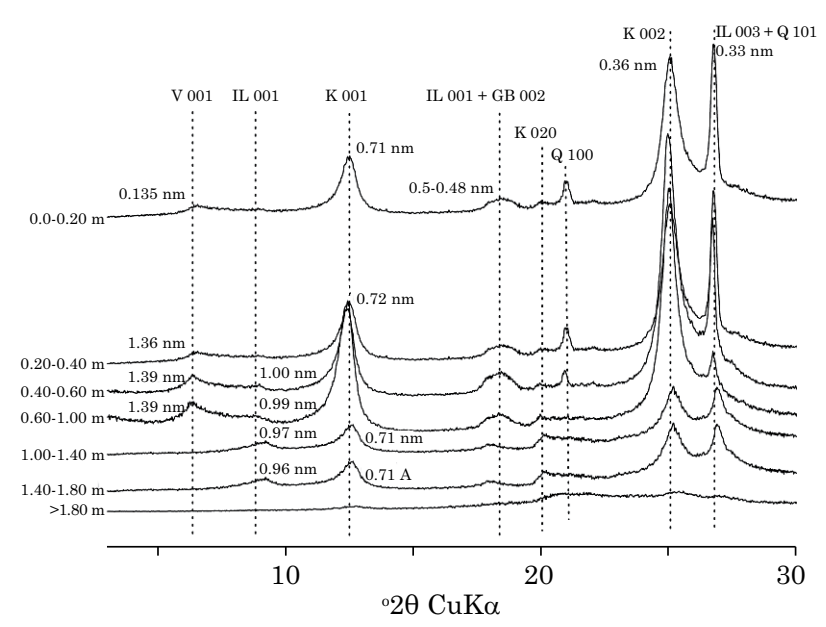

Figure 1. Sequence of $X$ ray diffractograms of clay fraction saturated with Mg, showing the morphology of the vermiculite, illite, and kaolinite peaks in different soil layers in Otacílio Costa, SC, Brazil. 
gibbsite and hematite, particularly in the A horizon. Therefore, organic compounds in soils induce the transformation of primary minerals to amorphous phases, to halloisite, and finally to kaolinite (Potter and Kämpf, 1981). This process was influenced by the dryer climate in the region at the beginning of pedogenesis, which changed to a more humid climate now (Kämpf and Klamt, 1978). This could explain the lack of gibbsite in this soil profile.

The weathering allows nutrients to be bioavailable and increases the soil surface layer (Vitousek, 2004). Over time, leaching decreases soil fertility. Thus, soil quality depends on internal factors such as organic matter content and quality, and soil texture and mineralogy, and external variables such as climate, hydrology, and topography (Fox, 2000). The analysis of mineralogical results and the nutrient stock of the soil suggests that these stands of P. taeda were enriched by nutrients brought by rainfall and atmospheric deposition. Although weathering is an important process for introducing nutrients into the soil (Fanning et al., 1989), the results of mineralogical analysis of the Cambissolo Húmico Alumínico léptico (Humic Endo-lithic Dystrudept) suggest that this process is no longer important, except for $\mathrm{K}, \mathrm{Ca}$, and $\mathrm{Mg}$, unless the long term is being considered. In the short term, the contribution of nutrients from atmospheric sources is much more important (Lima, 1985).

\section{Biomass sampling}

All components of tree biomass added up to $313 \mathrm{Mg} \mathrm{ha}^{-1}$ (Table 4). Wood was the largest component, with $62 \%$ of tree biomass. Bark represented $8 \%$ of tree biomass. The needles represented $2 \%$ of the tree biomass, the branches represented $11 \%$ of the tree biomass and the roots accounted for $17 \%$ of the total. Evaluating 26-year-old Pinus taeda, Oki (2002) found that wood accounted for roughly $75 \%$ of the tree biomass, the branches $16 \%$, the needles $6 \%$, and bark, $3 \%$. The order of biomass distribution was: wood $>$ root $>$ dead branches $>$ live branches $>$ bark $>$ needles, an order similar to that observed by Bizon (2005) for 25-year-old Pinus taeda in the same soil type.

The amount of accumulated litter was high, $27 \mathrm{Mg} \mathrm{ha}^{-1}$ (Figure 2). The highly decomposed litterfall in contact with the forest floor represented more than $50 \%$ of the total dry mass in the sample. Witschoreck (2008) found $14.9 \mathrm{Mg} \mathrm{ha}^{-1}$ for 17-year-old P. taeda.

Biomass accumulation is affected by environmental factors and the physiology of the plant itself (Kramer and Kozlowski, 1972). Biomass distribution within the tree components changes with age. There is a gradual decrease in canopy biomass and simultaneous increase in wood and bark biomass over time; and the latter represents, on average, more than $80 \%$ of the aboveground biomass in mature stands (Schumacher and Hoppe, 1997).
Table 4. Biomass and amount of nutrients accumulated in the components in 16-year-old Pinus taeda stands collected in Otacílio Costa, SC, Brazil

\begin{tabular}{|c|c|c|c|c|c|c|c|}
\hline Component & Biomass & $\mathbf{N}$ & $\mathbf{P}$ & $\mathbf{K}$ & $\mathbf{C a}$ & Mg & $\mathbf{S}$ \\
\hline & $\mathrm{Mg} \mathrm{ha}^{-1}$ & \multicolumn{6}{|c|}{$\mathrm{kg} \mathrm{ha}^{-1}$} \\
\hline Needle & 7 & 116 & 7 & 27 & 15 & 4 & 6 \\
\hline Live branche & 11 & 39 & 2 & 11 & 25 & 3 & 2 \\
\hline Dead branche & 22 & 70 & 1 & 3 & 16 & 8 & 8 \\
\hline Bark & 24 & 72 & 3 & 16 & 21 & 5 & 10 \\
\hline Wood & 195 & 210 & 33 & 85 & 91 & 31 & 65 \\
\hline $\operatorname{Root}^{(1)}$ & 54 & 365 & 10 & 54 & 130 & 30 & 49 \\
\hline Litterfall & 28 & 300 & 12 & 9 & 27 & 9 & 31 \\
\hline Total & 341 & 1,172 & 68 & 205 & 324 & 90 & 172 \\
\hline
\end{tabular}

(1) The depth of the primary coarser root (x, in $\mathrm{m})$ is related to the total tree height $(\mathrm{y}$, in $\mathrm{m}$ ) according to equation: $\hat{\mathrm{y}}=7.33+6.44 \mathrm{x}$ $\left(R^{2}=0.85 ; \mathrm{p}<0.0001\right)$.

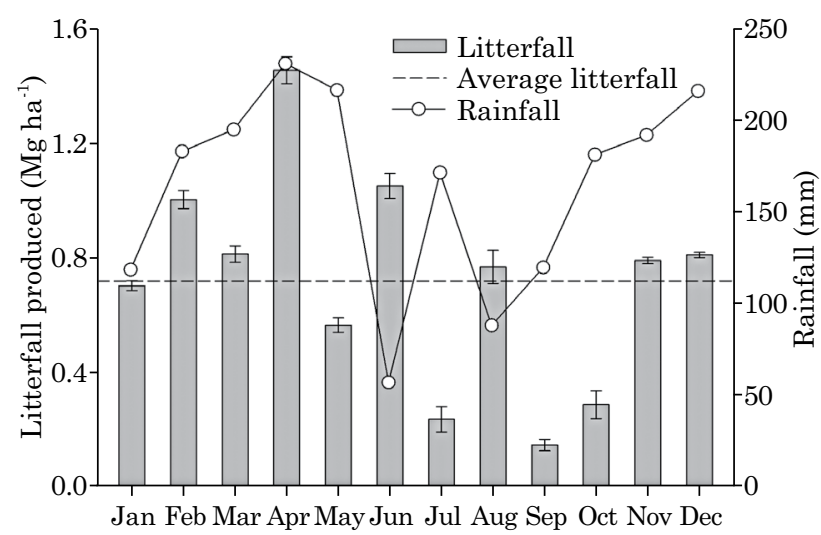

Figure 2. Monthly litter deposition and rainfall in 16-year-old Pinus taeda stands, in Otacílio Costa, SC, Brazil, January 2011 until December 2011.

Similar results were found in this study where the wood and bark were responsible for roughly $84 \%$ of the biomass.

Significant correlations were observed between the needle and wood components and the roots (Figure 3). These correlations, root vs. needles and root vs. wood, are of great importance for understanding the source/sink relationship in the tree, the growth process, and the allocation of $\mathrm{C}$ and nutrients to the various parts of the tree, which could explain the differences between their genotypic adaptabilities to different environmental stress conditions (Mello et al., 1998). The higher the correlation, the greater the efficiency in using assimilates. Forest productivity of $P$. taeda was studied by Bizon (2005) in different sites and attributed the difference in biomass allocation to the root component to the different productivity levels. 

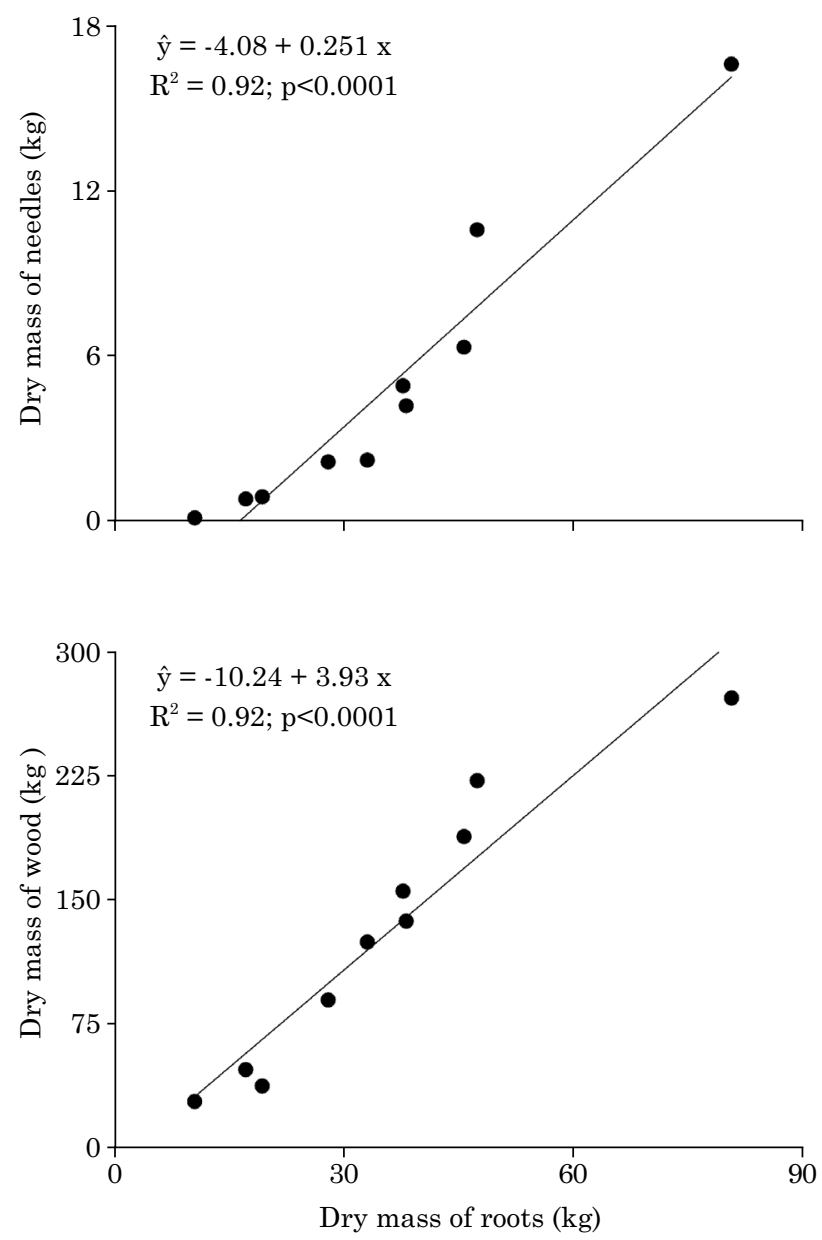

Figure 3. Relationship between dry mass of roots and dry mass of needles (a) and wood (b) collected in Otacílio Costa, SC, Brazil.

Regarding the content of nutrients accumulated in the different components, the following order was observed: full $\operatorname{root}>$ wood $>$ needles $>$ bark $>$ dead branches $>$ live branches (Table 4 ). This means that the wood continued to be one of the main components of nutrient stocks. However, the root component showed relatively large amounts of $\mathrm{N}, \mathrm{Ca}$, and $\mathrm{Mg}$. The crown showed high contents of $\mathrm{N}, \mathrm{K}$, and Ca. The litter was the component of biomass with the greatest accumulation of nutrients, especially, $\mathrm{N}$. The bark component had the lowest nutrient stock.

Nutrient stocks in the trees decreased in the following order: $\mathrm{N}>\mathrm{Ca}>\mathrm{K}>\mathrm{S}>\mathrm{Mg}>\mathrm{P}$, which is similar to the order obtained by Moro (2008). Although the largest components in biomass, namely wood and roots, showed higher nutrient stocks, there was no proportionality between biomass components and distribution of nutrients in the forest (Table 4). This is due to the difference in nutrient content in different components of the tree, as observed by Bizon (2005), who worked with the same soil type as used in this study. Considering, for example, total $\mathrm{N}$ in the biomass, $31 \%$ was found in the roots, $26 \%$ in the litter, $18 \%$ in the wood, $13 \%$ in the needles, $9 \%$ in the branches, and $6 \%$ in the bark. Hence, the crown accounts for roughly $15 \%$ of the biomass and stores $22 \%$ of the total N. The relative nutrient contents accumulated in these components were similar in the results of Bizon (2005).

Litter showed higher nutrient content than any biomass component, especially for $\mathrm{N}, \mathrm{P}$, and S. Plant litter improves the chemical and physical properties of the soil by incorporating organic matter, promoting root growth, and supplying nutrients to plants (Tonini, 2000).

Several aspects are involved in the maintenance of forest productivity (Switzer and Nelson, 1972; Kimmins, 1994; Gonçalves et al., 1997; Santana et al., 2002; Bizon, 2005; Witschoreck, 2008) and litter plays an essential role in accumulating most nutrients extracted by the trees from the soil. The storage, inflow, and outflow of nutrients have a fundamental function in the nutritional management of P. taeda plantings (Poggiani et al., 1998). Adequate management provides nutritional balance to natural forest ecosystems and planted forests because of continuous processes of nutrient cycling (Poggiani, 1985). In this context, nutrient stocks in the litter are of utmost importance for forest management, as they are related to nutrient cycling, especially in low fertility soils (Reis and Barros, 1990).

Average monthly litter deposition was $0.72 \mathrm{Mg} \mathrm{ha}^{-1}$ (Figure 2) with accumulated deposition of $8.6 \mathrm{Mg} \mathrm{ha}^{-1}$ a year. These values are similar to those observed by Koehler (1989). The largest deposition of litter occurred during the drier months, June and August. Seasonal variation in litter deposition occurred as follows: autumn>summer $>$ spring $>$ winter. The same result were found by Viera and Schumacher (2010) and Koehler (1989) and they did not observe a correlation between litter deposition and rainfall. Peak deposition may be related to extreme climatic factors, such as strong winds and periods of high humidity, which would accelerate the loss of senescent foliage in plants (Viera and Schumacher, 2010). Several studies have reported higher litter deposition in the drier periods of the year (Moreira and Silva, 2004; Mochiutti et al., 2006; Ferreira et al., 2007).

The results of the litter decomposition coefficient were low for Pinus spp. $(\mathrm{k}=0.3)$, showing that the average time for litter renewal was high $(1 / \mathrm{k}=3.2$ years $)$. Similarly, the decomposition of $50 \%$ and $95 \%$ were high, $\mathrm{t}_{0.5}=2.2$ and $\mathrm{t}_{0.05}=9.7$ years. The values obtained are consistent with results observed by Poggiani (1985), who found $\mathrm{k}=0.37$ for Pinus oocarpa and $\mathrm{k}=0.41$ for Pinus caribea var. hondurensis, with an average time for litter renewal of 2.4 and 2.7 years, respectively. 


\section{Sustainability scenarios}

The nutritional balance of the P. taeda planting and its prospects for long-term sustainability in wood production were highly dependent on the silvicultural scenarios considered. The intensity of nutrient export drastically affected the number of potential crop rotations (Table 5). This demonstrates the relative importance of forest components in forest management. Timber harvesting had the greatest impact, and the additional extraction of other biomass components, particularly those of high nutrient concentration such as canopies, greatly affects productivity sustainability of the planting. Although $\mathrm{N}$ and $\mathrm{Ca}$ were the nutrients exported in the greatest quantities in scenario A (timber harvesting only), their stocks in the soil and reserves in the biomass/litter were sufficiently high for them to sustain tree growth for many years. In contrast, although the export of $\mathrm{P}$, and to a lesser extent $\mathrm{S}$, were much lower at 33 and $65 \mathrm{~kg} \mathrm{ha}^{-1}$ over the 16 -year rotation, respectively, the stock in the soil and biomass were low in relation to these amounts exported. P. taeda, in a scenario of symbiosis with mycorrhizae, is very efficient at absorbing $\mathrm{P}$, and if $\mathrm{P}$ it is applied, $\mathrm{N}$ and $\mathrm{Ca}$ inventories would be enough to produce more than eight rotations (over 128 years); $\mathrm{K}$ and $\mathrm{Mg}$, more than five rotations (90 years); $\mathrm{P}$, more than three (42 years); and $\mathrm{S}$, more than four rotations (52 years). Although the analysis of this scenario does not consider all the inputs and outputs of the system, it provides a relative assessment of silvicultural practices regarding the long-term sustainability of productivity and provides a basis for decisions about the use of new practices for specific forest sites regarding edaphic quality (Gonçalves et al., 2008).

Although bark has less importance in terms of nutrient export, the removal of this component (Scenario B) resulted in reduction in recycling of $\mathrm{K}, \mathrm{Mg}$, and $\mathrm{S}$ compared to Scenario $\mathrm{A}$. $\mathrm{N}$ and $\mathrm{Ca}$ did not change, due to the greater stocks in the soil. Phosphorus also did not change, because P stocks in the bark are low. Regarding exhaustion of nutrients, the order for scenario B would be: $\mathrm{P}=\mathrm{S} \geq \mathrm{K}>\mathrm{Mg}>\mathrm{Ca}=\mathrm{N}$.

Table 5. An estimated nutrient budget and potential number of 16-year rotations under three management scenarios for plantings of Pinus taeda established in a Humic Endo-lithic Dystrudept (Mean Annual Increment of $33 \mathrm{~m}^{3} \mathrm{ha}^{-1} \mathrm{yr}^{-1}$ and total biomass of $341 \mathrm{Mg} \mathrm{ha}^{-1}$ )

\begin{tabular}{|c|c|c|c|c|c|c|}
\hline Component & $\mathbf{N}$ & $\mathbf{P}$ & $\mathbf{K}$ & $\mathbf{C a}$ & Mg & $\mathbf{S}$ \\
\hline & \multicolumn{6}{|c|}{$\mathrm{kg} \mathrm{ha}^{-1}$} \\
\hline Initial nutrient stock in the soil $(\mathrm{S} ; 0.00-1.90 \mathrm{~m})^{(1)}$ & 1,138 & 39 & 792 & 879 & 377 & 196 \\
\hline \multicolumn{7}{|l|}{ Nutrient stock in biomass $(\mathrm{Su})$} \\
\hline Needles & 116 & 7 & 27 & 15 & 4 & 6 \\
\hline Branches (dead and live) & 109 & 3 & 14 & 41 & 11 & 11 \\
\hline Wood & 210 & 33 & 85 & 91 & 31 & 65 \\
\hline Bark & 72 & 3 & 16 & 21 & 5 & 10 \\
\hline Litter & 300 & 12 & 9 & 27 & 9 & 31 \\
\hline Roots & 365 & 10 & 54 & 130 & 30 & 49 \\
\hline Sum & 1,172 & 68 & 205 & 324 & 90 & 172 \\
\hline \multicolumn{7}{|l|}{ Nutrient output } \\
\hline By removing wood (W) & 210 & 33 & 85 & 91 & 31 & 65 \\
\hline By removing bark and wood (B) & 282 & 36 & 101 & 112 & 36 & 75 \\
\hline By removing wood, bark, needles, and branches (AT) & 507 & 46 & 142 & 167 & 51 & 92 \\
\hline Nutrient input by rainfall (R) & 47 & 3 & 55 & 115 & 25 & 0 \\
\hline \multicolumn{7}{|c|}{ Nutrient budget ${ }^{(2)}$} \\
\hline Scenario A: $(\mathrm{S}+\mathrm{Su})-(\mathrm{W})+(\mathrm{R})$ & 2,026 & 69 & 742 & 996 & 364 & 263 \\
\hline Scenario B: $(\mathrm{S}+\mathrm{Su})-(\mathrm{W}+\mathrm{B})+(\mathrm{R})$ & 1,954 & 65 & 726 & 975 & 359 & 252 \\
\hline Scenario C: $(\mathrm{S}+\mathrm{Su})-(\mathrm{AT})+(\mathrm{R})$ & 1,729 & 55 & 684 & 919 & 344 & 235 \\
\hline \multicolumn{7}{|l|}{ Potential number of sixteen-year rotations } \\
\hline Scenario A & $>8$ & 3 & 6 & $>8$ & 6 & 4 \\
\hline Scenario B & $>8$ & 3 & 5 & $>8$ & 5 & 3 \\
\hline Scenario C & 7 & 2 & 3 & 5 & 3 & 3 \\
\hline
\end{tabular}

(1) Only potentially mineralizable N (Gonçalves et al., 2001), resin-extractable P, and exchangeable K, Ca, and Mg; ${ }^{(2)} \mathrm{Nutrients}$ remaining at the site after the first 16 -year rotation. 
The additional extraction of the canopy (Scenario C) would decrease the number of forest rotations compared to Scenario B. This is because the crown has a high concentration of nutrients, some of which have low stocks in the soil, which increases the rate of their exhaustion. The removal of $\mathrm{N}$ stored in the crown would cause a reduction of two rotations, even with high stocks in the soil. The limitation order for scenario $\mathrm{C}$ would be: $\mathrm{P}>\mathrm{S}=\mathrm{K}=\mathrm{Mg}>\mathrm{Ca}>\mathrm{N}$.

Nutrient input from rainfall was significant for the nutrient balance in the three scenarios presented. Considering the long period of P. taeda management, all inputs were considered very important for the balance of inputs and outputs in the forest system. Although these inputs do not compensate for the nutrient removal, even for wood removal only (except for $\mathrm{Ca}$ ), the additional nutritional contribution of rainfall can be significant for the nutritional management of $P$. taeda at the study site. Pinus spp. has been cultivated since the 1960 s, with no record of fertilization practices in Brazil. Rainwater interacts with the tree crowns and bark, leaching appreciable amounts of nutrients (Lima and Barbin, 1975), and this becomes an important source of nutritional replacement in forest plantations (Caldato, 2011).

Analyzing productivity at the site from a nutritional perspective, Lima (1985) considered that the maintenance of forest productivity over successive forest rotations depends on the speed of new nutrient release by weathering and rains. However, on the scale of use of soil nutrients throughout the forests, the dependence on nutrient input via rainfall is more significant, given that rain constitutes an important nutrient source for forest ecosystems.

Analysis of the scenarios proposed without considering all the inputs and outputs of the system provided a relative assessment of silvicultural practices in regard to the sustainability of long-term wood production. Therefore, this analysis is a basis for decision-making on the use of new practices for specific forest sites in terms of their edaphic quality (Gonçalves et al., 2008). The relative evaluation of the results from the different scenarios (forestry practices) regarding the potential of maintaining forest production in continuous rotations proved to be an important tool since the analysis provided a better understanding and prediction of impacts from different forest management practices as limiting factors (Fox, 2000).

\section{CONCLUSIONS}

The management scenarios analyzed influenced sustainable productivity of Pinus taeda, modifying the projected number of forest rotations. The most significant effect was observed for scenario C, due to crown removal. Although all the nutrients in the soil studied are sufficient, crown removal is the only scenario that alters the number of forest rotations in all the nutrients studied.

The release of $\mathrm{K}$ by minerals to the soil solution is likely triggered by the weathering of illite or primary mica minerals, which are transformed into other clay minerals such as vermiculite. Thus, this process of mineralogical conversion gradually releases $\mathrm{K}$ to the solution as weathering progresses.

Although the nutritional level of the soil significantly influences the number of forest rotations, special attention should be given to the management of forest components, mainly the branches and needles. Furthermore, forest managers should look for adequate nutrient replenishment. The results of our study show that due to the current system developed on the site (scenario C), nutritional sustainability may be compromised in the short-term.

\section{ACKNOWLEDGMENTS}

We acknowledge the National Council for Scientific and Technological Development (CNPq) and Klabin S/A for their financial support. We thank Kevin Hall (NCSU) for carefully reviewing the English language. We are grateful to Dr. Itamar Bognola (Embrapa) for the translation of soil types between Brazilian and American soil taxonomic systems.

\section{REFERENCES}

Adams MB, Burger JA, Jenkins AB, Zelazny L. Impact of harvesting and atmospheric pollution on nutrient depletion of eastern US hardwood forests. For Ecol Manage. 2000;138:301-19.

Alvares CA, Stape JL, Sentelhas PC, Gonçalves JLM. Modeling monthly mean air temperature for Brazil. Theor Appl Climatol. 2013a;113:407-27.

Alvares CA, Stape JL, Sentelhas PC, Gonçalves JLM, Sparovek G. Köppen's climate classification map for Brazil. Meteorol Zeitschrift. 2013b;22:711-28.

Alvares CA, Mattos EM, Sentelhas PC, Miranda AC, Stape JL. Modeling temporal and spatial variability of leaf wetness duration in Brazil. Theor Appl Climatol. 2015;120:455-67.

Antonello LL, Wittern KP, Claessen MEC, Bertolino LC. Mineralogia e química de algumas unidades de solos do Estado do Rio de Janeiro. Bol Pesq Desenv. 2002;15:3-22.

Banfield JF, Eggleton RA. Analytical transmission electron microscope study of plagioclase, muscovite and K-feldspar weathering. Clays Clay Miner. 1990;38:77-89.

Bellote AFJ, Dedecek RA. Atributos físicos e químicos do solo e suas relações com o crescimento e a produtividade do Pinus taeda. Bol Pesq Flor. 2006;53:21-38. 
Betiollo LM. Caracterização estrutural, hidrogeológica e hidroquímica dos sistemas aquiferos Guarani e Serra Geral no Nordeste do Rio Grande do Sul, Brasil. Porto Alegre: Universidade Federal do Rio Grande do Sul; 2006.

Bizon JMC. Avaliação da sustentabilidade nutricional de plantios de Pinus taeda L. usando um balanço de entrada-saída de nutrientes [dissertação]. Piracicaba: Escola Superior de Agricultura "Luiz de Queiroz"; 2005.

Brito JO, Barrichelo LEG, Couto HTZ, Mendes CJ, Rezende GC. Estudo do comportamento de madeira de eucalipto frente ao processo de destilação seca. R Brasil Flor. 1984;8:5-48.

Caldato SL. Ciclagem biogeoquímica dos nutrientes em uma plantação de Pinus taeda L. no nordeste argentino [tese]. Santa Maria: Universidade Federal de Santa Maria; 2011.

Empresa Brasileira de Pesquisa Agropecuária - Embrapa. Centro Nacional de Pesquisa do Solo. Manual de métodos de análise de solo. $2^{\mathrm{a}}$.ed. Rio de Janeiro: 1997.

Fanning DS, Keramidas VZ, El-Desoky MA. Micas. In: Dixon JB, Weed SB, editors. Minerals in soils environments. $2^{\text {nd }} . e d$. Madison: Soil Science Society of America; 1989. p.551-634.

Ferreira RLC, Lira Jr. MA, Rocha MS, Santos MVF, Lira MA, Barreto LP. Deposição e acúmulo de matéria seca e nutrientes em serapilheira em um bosque de sabiá (Mimosa caesalpiniifolia Benth.). R Árvore. 2007;31:7-12.

Fox TR. Sustained productivity in intensively managed forest plantations. For Ecol Manage. 2000;138:187-202.

Jackson ML. Soil chemical analysis: Advanced course. Madison: Wisconsin University; 1973.

Gonçalves GA, Ramalho MAP, Andrade HB, Marques OGM. Resposta na segunda rotação pela seleção efetuada na primeira, em família de meios-irmãos de Eucalyptus grandis Hill ex Maiden. R Árvore, 1997;21:377-83.

Gonçalves JLM, Stape JL, Laclau JP, Bouillet JP, Ranger J. Assessing the effects of early silvicultural management on long-term site productivity of fast-growing eucalypt plantations: the Brazilian experience. Southern For. 2008;70:105-18.

Gonçalves JLM, Alvares CA, Higa AR, Silva LD, Alfenas AC, Stahl J, Ferraz SFB, Lima WP, Brancalion PHS, Hubner A, Bouillet JPD, Laclau JP, Nouvellon Y, Epron D. Integrating genetic and silvicultural strategies to minimize abiotic and biotic constraints in Brazilian eucalypt plantations. For Ecol Manage. 2013;301:6-27.

Gonçalves JLM, Silva LD, Behling M, Alvares CA. Management of industrial plantations. In: Borges JG, Diaz-Balteiro L, Mcdill ME, Rodriguez LCE, editors. The management of industrial forest plantations - theoretical foundations and applications. Dordrecht: Springer; 2014. p.91-119.

Kämpf N, Klamt E. Mineralogia e gênese de Latossolos (Oxisols) e solos Podzólicos da Região Nordeste do Planalto Sul-Riograndense. R Bras Ci Solo. 1978;2:68-73.

Kämpf N, Curi N, Marques JJ. Intemperismo e ocorrência de minerais no ambiente do solo. In: Alleoni LRF, Melo VF, editores. Química e mineralogia do solo. Viçosa, MG: Sociedade Brasileira de Ciência do Solo; 2009. v.1, p.333-80.

Kimmins JP. Identifying key processes affecting long-term site productivity. In: Dyck WJ, Cole DW, Comerford NB, editors. Impacts of forest harvesting on long-term site productivity. Vancouver [CA]: 1994. p.119-50.
Koehler WC. Variação estacional de deposição de serapilheira e de nutrientes em povoamentos de Pinus taeda na região de Ponta Grossa, PR [dissertação]. Curitiba: Universidade Federal do Paraná; 1989.

Kramer PJ, Kozlowski T. Physiology of trees. Lisboa [PT]: Fundação Calouste Gulbenkian; 1972.

Lima WP. Ação das chuvas no ciclo biogeoquímico de nutrientes em plantações de pinheiros tropicais e em cerradão. Inst Pesq Est Flor. 1985;30:13-7.

Lima WP, Barbin D. Efeito de plantações de Eucalyptus e Pinus sobre a qualidade da água da chuva. IPEF. 1975;11:23-35.

Machado FB, Moreira CA, Godoy AM, Zanardo A, Nardy AJR. Modernização da litoteca e do museu de minerais e rochas prof. Dr. Heinz Ebert através de um banco de dados para consulta local e remota. Rio de Janeiro: Universidade Estadual do Rio de Janeiro; 2001.

Malavolta E, Vitti GC, Oliveira SA. Avaliação do estado nutricional das plantas: princípios e aplicações. Piracicaba: Potafos; 1989.

Mello SLM, Gonçalves JLM. Equações para estimar a biomassa da parte aérea e do sistema radicular em povoamentos de Eucalyptus grandis em sítios com produtividades distintas. $\mathrm{R}$ Árvore. 2008;32:101-11.

Mello SLM, Gonçalves JLM, Oliveira LEG. Características do sistema radicular em povoamentos de eucaliptos propagados por sementes e estacas. Sci For. 1998;54:17-28.

Mochiutti S, Queiroz JAL, Melém Junior NJ. Produção de serapilheira e retorno de nutrientes de um povoamento de taxi-branco e de uma Floresta Secundária no Amapá. Bol Pesq Flor. 2006;52:3-20.

Moore DM, Reynolds RC. X-ray Diffraction and the Identification and analysis of clay minerals. 2nd. ed. New York: University Press; 1997.

Moreira PR, Silva OA. Produção de serapilheira em área reflorestada. R Árvore. 2004;28:49-59.

Moro L. Exportação de nutrientes em povoamentos de Pinus taeda L. Baseada em volume estimado pelo sistema SISPINUS. Floresta. 2008;38:465-77.

Munhoz JSB. Caracterização da produtividade florestal e dos padrões de crescimento de Pinus taeda L. no sul do Brasil através de análise de tronco [dissertação]. Piracicaba: Escola Superior de Agricultura "Luiz de Queiroz"; 2011.

Norrish K. Forces between clay particles. In: Serratosa JM, editor. International Clay Conference - CSIA. Madrid [ES]: 1973. p.375-83.

Oki VK. Impactos da colheita de Pinus taeda sobre o balanço hídrico, a qualidade da água e a ciclagem de nutrientes em microbacias [dissertação]. Piracicaba: Escola Superior de Agricultura "Luiz de Queiroz"; 2002.

Olson JS. Energy storage and the balance of producers and decomposers in ecological systems. Ecology. 1963;44: 322-31.

Poggiani F. Ciclagem de nutrientes em ecossistemas de plantações florestais de Eucalyptus e Pinus: implicações silviculturais [tese]. Piracicaba: Escola Superior de Agricultura "Luiz de Queiroz"; 1985.

Poggiani F, Stape JL, Gonçalves JLM. Indicadores de sustentabilidade das plantações florestais. IPEF. 1998;12:33-44. 
Potter RO, Kämpf N. Argilo-minerais e óxidos de ferro em Cambissolos e Latossolos sob regime climático térmico údico no Rio Grande do Sul. R Bras Ci Solo. 1981;5:153-9.

Programa de Monitoramento Ambiental em Microbacias - PROMAB. Relatório Técnico Anual. Piracicaba: 2011.

Raij Bvan, Andrade JC, Cantarella H, Quaggio JA. Análise química para avaliação da fertilidade de solos tropicais. Campinas: Instituto Agronômico de Campinas; 2001.

Reis MGF, Barros NF. Ciclagem de nutrientes em plantios de eucalipto. In: Barros NF, Novais RF, editores. Relação solo-eucalipto. Viçosa, MG: Folha de Viçosa; 1990. p.265-302.

Santa Catarina. Atlas de Santa Catarina. Gabinete de Planejamento e coordenação Geral. Subchefia de Estatística, Geografia e Informática. Rio de Janeiro: Aerofoto Cruzeiro; 1986.

Santana RC, Barros NF, Neves JCL. Eficiência de utilização de nutrientes e sustentabilidade da produção em procedências de Eucalyptus grandis e Eucalyptus saligna em sítios florestais do Estado de São Paulo. R Árvore. 2002;26:447-57.

Schumacher MV, Poggiani F. Produção de biomassa e remoção de nutrientes em povoamentos de Eucalyptus camaldulensis Dehnh, Eucalyptus grandis Hill ex Maiden e Eucalyptus torelliana F. Muell, plantados em Anhembi, SP. Ci Flor. 1993;3:21-34.

Schumacher MV, Hoppe JM. A complexidade dos ecossistemas. Porto Alegre: Pallotti; 1997.
Shanks R, Olson JS. First year breakdown of leaf litter in Southern Appalachia. For Sci. 1961;134:194-5.

Smalian HL. Beitrag zur holzmesskunst. Stralsund: 1837.

Soares RV, Hosokawa RT. Estimativa da biomassa energética de árvores de bracatinga (Mimosa scabrella Benth). Brasil Flor: Bol Técnico. 1984;8:37-48.

Statistical Package for the Social Science. SigmaPlot for Windows: version 2010. Chicago: 2006.

Switzer GL, Nelson LE. Nutrient accumulation and cycling in loblolly pine (Pinus taeda L) plantation ecosystems: the first twenty years. Soil Sci Soc Am Proc. 1972;36:143-7.

Tonini H. Crescimento em altura de Pinus elliottii Engel, em três unidades de mapeamento de solo, nas regiões da serra do sudeste e litoral, no estado do Rio Grande do Sul [dissertação]. Santa Maria: Universidade Federal de Santa Maria; 2000.

Viera M, Schumacher MV. Teores e aporte de nutrientes na serapilheira de Pinus taeda L., e sua relação com a temperatura do ar e pluviosidade. R Árvore. 2010;34:85-94.

Vitousek P. Nutrient cycling and limitation: Hawai'i as a model system. Princenton: Princeton University Press; 2004.

Witschoreck R. Biomassa e nutrientes no corte raso de um povoamento de Pinus taeda L. de 17 anos de idade no município de Cambará do Sul - RS [dissertação]. Santa Maria: Universidade de Santa Maria; 2008. 